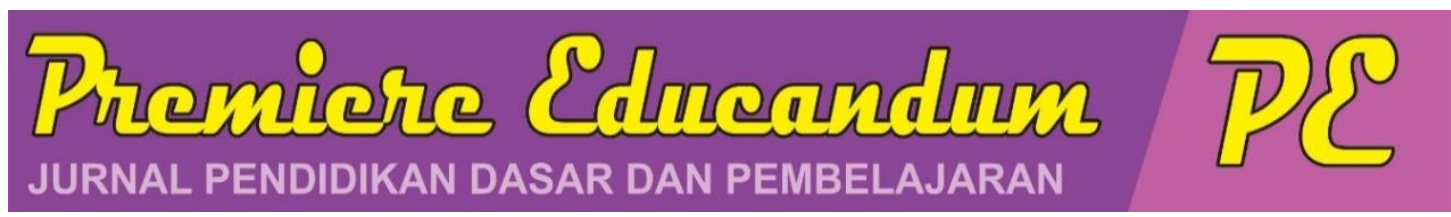

Premiere Educandum: Jurnal Pendidikan Dasar dan Pembelajaran

Volume 9 (2) 123 - 129 Desember 2019

Copyright @2019 Universitas PGRI Madiun

ISSN: 2088-5350 (Print) / ISSN: 2528-5173 (Online)

Available at: http://e-journal.unipma.ac.id/index.php/PE

Doi: $10.25273 /$ pe.v9i2.4887

\title{
Pemahaman konsep operasi hitung penjumlahan bilangan cacah siswa sekolah dasar
}

\author{
Karlimah $^{1)}$, Lutfi Nur ${ }^{2)}$, \& Hani Oktaviyani1) \\ 1,2,3 UPI Kampus Tasikmalaya \\ 1email: karlimah@upi.edu \\ 2email: lutfinur@upi.edu \\ 3 email: hanioktaviyani@student.upi.edu
}

\begin{abstract}
This study aims to determine the conditions of understanding the concept of calculating the sum operations of elementary school students. This research uses a descriptive method. The subjects in this study were 24 grade I primary school students. Data collection techniques in this study were as many as 10 items of essay tests with a validity value of 0.77 and reliability of 0.92 and a level of distinguishing power of 0.42 , which means it is in the good value category. This research is located at SDN 1 Nagasari in Tasikmalaya City, Indonesia. Data analysis techniques in this study used descriptive statistics. The results showed that the ability to comprehend the concept of counting operations of counting numbers in elementary school students in first grade was still not optimal. The findings of this study can provide an overview to the teachers, so that it becomes an evaluation material for the learning process.
\end{abstract}

Keywords: Arithmetic Operations, Chopped Number, Elementary School Student.

\section{Abstrak}

Penelitian ini bertujuan untuk mengetahui kondisi pemahaman konsep operasi hitung penjumlahan bilangan cacah siswa sekolah dasar. Penelitian ini menggunakan metode deskriptif. Subyek dalam penelitian ini adalah siswa sekolah dasar kelas I (satu) yang berjumlah 24 orang. Teknik pengumpulan data yang digunakan adalah tes essay sebanyak 10 butir soal dengan nilai validitas 0,77 dan reliabilitas 0,92 serta mempunyai tingkat daya pembeda 0,42 yang artinya berada dalam kategori nilai baik. Penelitian ini bertempat di SDN 1 Nagasari Kota Tasikmalaya, Indonesia. Teknik analisis data dalam penelitian ini menggunakan statistik deskriptif. Hasil penelitian menunjukkan bahwa kemampuan pemahaman konsep operasi hitung penjumlahan bilangan cacah pada siswa sekolah dasar di kelas satu masih belum optimal. Adanya temuan dari hasil penelitian tentang kesalahan siswa dalam penggunaan nilai tempat merupakan informasi penting bagi para guru, sehingga menjadi bahan evaluasi untuk proses pembelajaran.

Kata Kunci: Operasi Hitung, Bilangan Cacah, Siswa Sekolah Dasar.

Histori artikel : disubmit pada 03 Agustus 2019; direvisi pada 27 September 2019; diterima pada 18 Oktober 2019

\section{A. PENDAHULUAN}

Mata pelajaran matematika bertujuan agar peserta didik memiliki kemampuan memahami konsep matematika, menjelaskan keterkaitan antar konsep dan mengaplikasikan konsep atau algoritma, secara luwes, akurat, efisien, dan tepat dalam pemecahan masalah (Depdiknas, 2006). Matematika merupakan salah satu bidang studi yang diajarkan pada 
tingkat pendidikan sekolah dasar (Astuty \& Wijayanti, 2013).

Penguasaan pelajaran matematika dirasa sangat penting oleh para siswa sekolah dasar (Siagian, 2016; Widyastuti \& Pujiastuti, 2014). Hal ini berkaitan erat dengan hakikat pembelajaran matematika diantaranya dikaitkan dengan penerapannya dalam kehidupan sehari-hari di masyarakat (Sulianto, 2008).

Pemahaman konsep matematika merupakan bagian penting yang harus dipelajari oleh siswa karena sering dibutuhkan dan diimplementasikan pada aktivitas sehari-harinya, baik di sekolah, di rumah maupun di lingkungan masyarakat (Ainurrohmah \& Mariana, 2018). Dalam pembelajaran matematika, penguatan konsep merupakan hal yang penting (Arnidha, 2015).

Namun, dalam praktiknya pembelajaran matematika dirasakan sulit dan tidak menyenangkan bagi kebanyakan siswa, selain itu banyak guru mengajarkannya tidak menarik, dimana guru hanya menerangkan sementara siswa hanya mencatat, Zulkardi dan Russefendi (dalam Putri, 2011).

Dalam materi pelajaran matematika terkait pemahaman konsep yang harus dimiliki para siswa diantaranya adalah pemahaman operasi hitung (Heather C. Hill, 2008). Karena hal tersebut dapat kita temui kebutuhannya dalam kehidupan sehari-hari sehingga siswa yang mempunyai pemahaman yang baik dapat membantu dalam menjalani interaksi kehidupan lebih baik dibandingkan yang belum mampu (Mulyani, Suarjana, \& Renda, 2018). Selain itu, menjadi dasar pemahaman konsep matematika selanjutnya.

Meskipun disisi lain pemahaman konsep operasi hitung dirasa sangat penting untuk dimiliki para siswa, namun penelitian mengungkapkan masih rendahnya pemahaman siswa mengenai operasi hitung, salah satunya mengenai pengurangan bilangan bulat (Nurhaeni, Pranata dan Respati, 2019; Andhani dan Nur'aeni, 2019).

Penelitian lainnya dilakukan oleh Imelda, Yusmin, \& Suratman (2014); Utami (2016) dalam penelitiannya menyatakan bahwa kondisi siswa masih mengalami kesulitan dalam menyelesaikan soal operasi hitung campuran pada bilangan bulat.

Studi pendahuluan untuk mengungkap kondisi pemahaman mengenai operasi bilangan bulat sudah cukup banyak dilakukan seperti yang sudah diuraikan di atas. Namun, masih sedikit penelitian yang mengungkap tentang kemampuan pemahaman konsep operasi hitung penjumlahan bilangan cacah. Oleh karena itu, peneliti bertujuan untuk mengetahui kondisi kemampuan pemahaman konsep operasi hitung penjumlahan bilangan cacah pada siswa sekolah dasar.

\section{B. METODE PENELITIAN}

Penelitian ini menggunakan metode deskriptif. Peneliti tidak memberikan suatu perlakuan tertentu terhadap sampel, tetapi hanya melihat suatu fenomena berdasarkan data pada suatu kelompok. Selain itu dalam penelitian ini peneliti hanya menggunakan statistik deskriptif sesuai dengan kebutuhannya yaitu menggambarkan kondisi kemampuan pemahaman konsep dasar operasi hitung penjumlahan bilangan cacah pada siswa sekolah dasar dengan menggunakan tabel dan atau grafik dengan kategori sangat tinggi, tinggi, sedang, rendah, sangat rendah. Penelitian dilaksanakan di SDN 1 Nagarasari Kota Tasikmalaya. Jumlah sampel dalam penelitian ini sebanyak 
24 siswa kelas satu. Instrumen yang digunakan dalam penelitian ini beupa tes essay sebanyak sepuluh soal dengan memiliki tingkat validitas 0,77 dan reliabilitas 0,92 serta mempunyai daya pembeda sebesar 0,42 yang berarti masuk dalam kategori baik. Berikut ini merupakan indikator soal tes yang digunakan dalam penelitian ini.

Tabel 1. Indikator Soal Tes Operasi Hitung Penjumlahan Bilangan Cacah (Oktaviyani dan Karlimah, 2019)

\begin{tabular}{|c|c|c|c|c|c|}
\hline $\begin{array}{c}\text { Standar } \\
\text { Kompetensi }\end{array}$ & $\begin{array}{c}\text { Kompetensi } \\
\text { Dasar }\end{array}$ & Indikator & $\begin{array}{c}\text { Nomor } \\
\text { Soal }\end{array}$ & Tingkat Kognitif & $\begin{array}{c}\text { Tingkat } \\
\text { Kesukaran }\end{array}$ \\
\hline $\begin{array}{l}\text { 4. Melakukan } \\
\text { penjumlahan } \\
\text { dan } \\
\text { pengurangan } \\
\text { bilangan } \\
\text { sampai dua } \\
\text { angka dalam } \\
\text { pemecahan } \\
\text { masalah. }\end{array}$ & $\begin{array}{l}\text { 4.1 Melakukan } \\
\text { operasi } \\
\text { penjumlahan } \\
\text { bilangan dua } \\
\text { angka }\end{array}$ & $\begin{array}{l}\text { 4.1.1 Menjumlah } \\
\text { dua bilangan } \\
\text { tanpa teknik } \\
\text { menyimpan } \\
\text { 4.1.2 Menjumlah } \\
\text { bilangan dengan } \\
\text { satu kali teknik } \\
\text { menyimpan } \\
4.1 .3 \\
\text { Menyelesaikan } \\
\text { soal cerita yang } \\
\text { berhubungan } \\
\text { dengan } \\
\text { penjumlahan }\end{array}$ & $\begin{array}{l}1,2 \\
3,4 \\
5,6\end{array}$ & $\begin{array}{c}\mathrm{C} 2 \\
\text { (Memahami) } \\
\mathrm{C} 2 \\
\text { (Memahami) }\end{array}$ & $\begin{array}{l}\text { Mudah } \\
\text { Sedang } \\
\text { Sukar } \\
\text { Sedang }\end{array}$ \\
\hline
\end{tabular}

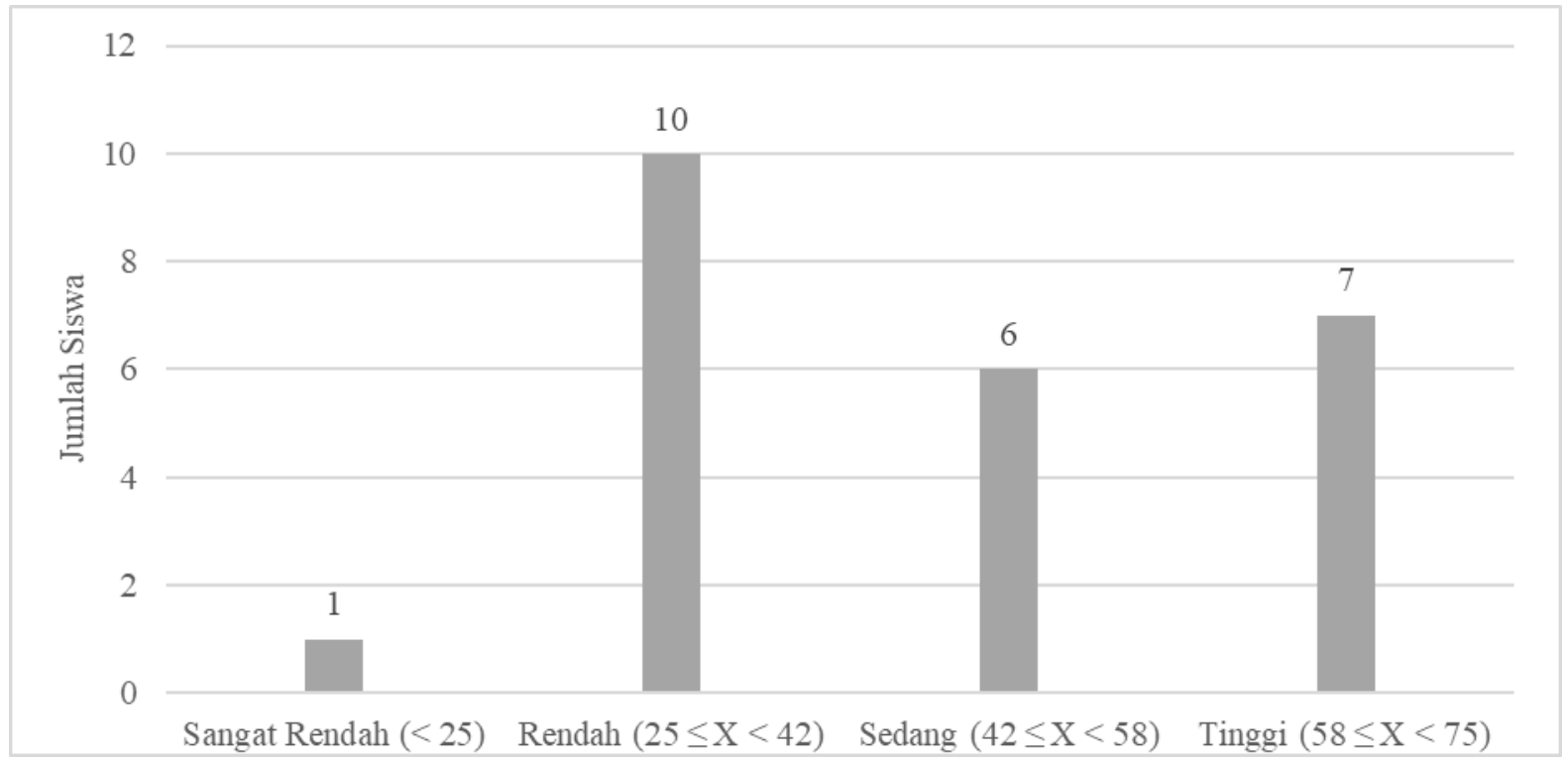

Gambar 1. Pemahaman Konsep Operasi Hitung Penjumlahan Bilangan Cacah pada Siswa SD

\section{HASIL DAN PEMBAHASAN}

Data hasil menggambarkan penelitian kemampuan pemahaman konsep operasi hitung penjumlahan bilangan cacah pada siswa sekolah dasar kelas satu. 
Adapun ringkasan deskripsi data hasil penelitiannya dapat dilihat pada Gambar 1.

Gambar 1 menunjukkan bahwa dari 24 siswa yang mengerjakan soal essay dapat digambarkan bahwa nilai tertinggi terletak pada interval $58 \leq \mathrm{X}$ $<75$ oleh 7 orang siswa dan nilai terendah terletak pada interval $\mathrm{X}<25$ oleh 1 orang siswa . Selain itu, diperoleh rerata 44,38 serta standar deviasi 14,09. Untuk lebih memperjelas kondisi pemahaman konsep operasi hitung bilangan cacah siswa, berikut digambarkan kategori penilaian serta pencapaian persentase pada tabel 2 .

Tabel 2. Deskripsi Kategori Penilaian Pemahaman Konsep Operasi Hitung Bilangan Cacah

\begin{tabular}{lcccc}
\hline No & Interval Nilai & Kategori & Frekuensi & Persentase \\
\hline 1 & $\mathrm{X} \geq 75$ & Sangat Tinggi & 0 & $0 \%$ \\
\hline 2 & $58 \leq X<75$ & Tinggi & 7 & $29 \%$ \\
\hline 3 & $42 \leq X<58$ & Sedang & 6 & $25 \%$ \\
\hline 4 & $25 \leq X<42$ & Rendah & 10 & $42 \%$ \\
\hline 5 & $X<25$ & Sangat Rendah & 1 & $4 \%$ \\
\hline
\end{tabular}

Berdasarkan tabel 3 dapat diketahui bahwa pemahaman konsep siswa pada materi operasi hitung penjumlahan bilangan cacah di kelas satu sekolah dasar memiliki empat kategori yaitu sebanyak 1 orang (sangat rendah), 10 orang (rendah), 6 orang (sedang), 7 orang (tinggi). Artinya apabila di ambil rata-rata dari keseluruhan pencapaian siswa dalam pemahaman konsep operasi hitung penjumlahan cacah berada dalam kategori sedang dengan nilai 44,38.

Berdasarkan pengumpulan dan pengolahan data hasil observasi penelitian dilapangan menunjukkan perolehan skor secara keseluruhan mempunyai nilai rata-rata 44,38. Artinya kemampuan pemahaman konsep operasi hitungan penjumlahan bilangan cacah berada dalam batas bawah kategori sedang atau dengan kata lain belum optimalnya kemampuan pemahaman konsep para siswa sekolah dasar di kelas satu.

Operasi hitung penjumlahan adalah pengerjaan menjumlah pada bilangan untuk menentukan hasil penjumlahan dari dua bilangan atau lebih (Arnidha, 2015; Imelda et al., 2014). Sedangkan bilangan cacah merupakan banyaknya anggota suatu himpunan terdiri dari himpunan yang memiliki anggota dan himpunan yang tidak memiliki anggota. Bilangan cacah teriri dari bilangan asli dan nol (Oktaviyani \& Karlimah, 2019; Suryowati, 2016). Urutan bilangan cacah dimulai dari $0,1,2,3,4,5$, dan seterusnya. Dengan demikian operasi hitung penjumlahan bilangan cacah merupakan gabungan dari sekelompok bilangan atau lebih sehingga menjadi suatu bilangan yang merupakan jumlah.

Contoh: $4+3=7$

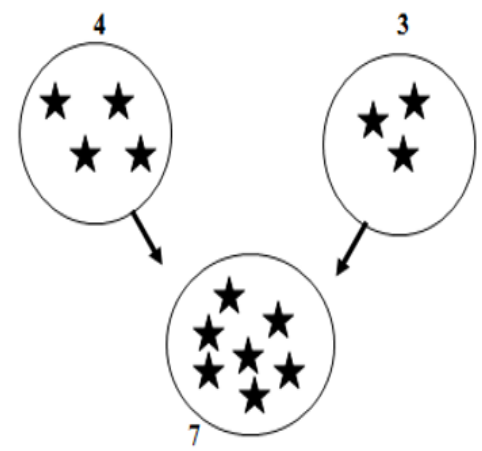

Gambar 2. Contoh Operasi Hitung Penjumlahan

Gambar 2 Menunjukkan visualisasi penjumlahan $4+3$ yang digambarkan dalam himpunan beranggotakan 4 dan 3 digabung menjadi himpunan yang beranggotakan 7 . 
Penjumlahan dengan cara bersusun panjang dan teknik menyimpan, diselesaikan dengan cara berikut:

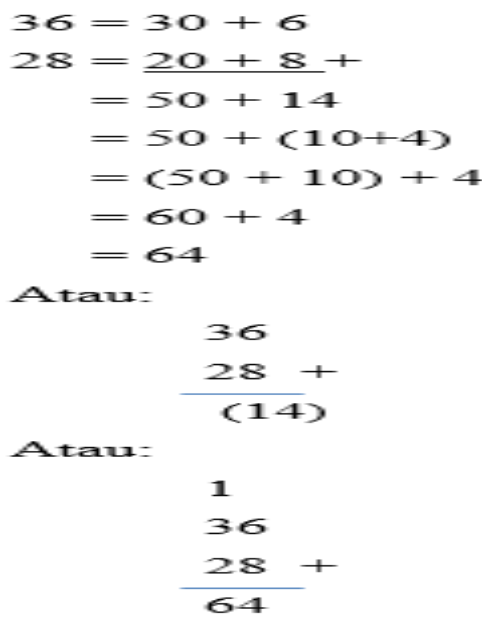

Dalam praktiknya dilapangan proses pembelajaran yang dilakukan oleh guru sering mengalami hambatan-hambatan mengenai materi operasi bilangan, seperti pengajaran yang kurang menarik, minimnya kreativitas juga keterbatasan media sehingga dampaknya terlihat pada belum optimalnya kemampuan pemahaman operasi hitung penjumlahan pada siswa (Dewi \& Haryanto, 2019; Fitriana, 2016; Putri, 2011).

Beberapa penelitian mengungkapkan hasil analisisnya mengenai kendala atau kesulitan dalam pengerjaan penjumlahan bilangan cacah (Arnidha, 2015; Astuty \& Wijayanti, 2013; Ugi, Djadir, \& Darwis, 2016) diantaranya jenis kesalahannya dikelompokkan menjadi dua, yaitu pertama fakta dasar penjumlahan. Letak kesalahannya ketika mereka melakukan kesalahan pada saat menjumlahkan dua bilangan. Prosedur yang digunakan sudah benar, tetapi dalam menentukan hasil penjumlahan salah. Lupa menyimpan hasil pada saat menjumlahkan satuan dengan satuan, puluhan dengan puluhan.

Kedua kesalahan acak. Jenis kesalahan ini dilakukan oleh responden ketika siswa mengerjakan soal penjumlahan bersusun pendek. Siswa memberikan jawaban tetapi salah atau tidak menunjukkan keteraturan atau alasan tertentu. Pada kesalahan acak ini siswa tidak dapat menjelaskan apa yang ditulisnya.

Keadaan tersebut juga dilaporkan Ashlock (dalam Wahyudi, 2009) bahwa dari hasil wawancara dengan siswa, terdapat $3 \%$ yang diabaikan karena mereka tidak dapt memberikan alasan dari jawaban yang ditulis.

Penyebabnya dimungkinkan karena kurangnya konsentrasi siswa dalam mengerjakan soal operasi hitung penjumlahan, siswa kurang menguasai konsep penjumlahan atau teknik pemindahan pada penjumlahan, dan terbatasnya waktu untuk mengerjakan soal tersebut. Selain itu, disebutkan bahwa kesalahan mendasar pada operasi hitung penjumlahan bilangan cacah sangat bervariasi, diantaranya siswa tidak memahami konsep dasar penjumlahan dan memahami teknik simpanan dengan baik (Arnidha, 2015).

Berdasarkan konsep, teori, hasil penelitian dan temuan dilapangan dapat disimpulkan bahwa kemampuan pemahaman konsep operasi hitung penjumlahan bilangan cacah masih belum optimal. Hal ini dikarenakan banyak faktor yang mempengaruhinya, seperti guru, siswa, peralatan pembelajaran dan lain sebagainya yang terkait dengan proses belajar mengajar.

\section{SIMPULAN}

Hasil penelitian menunjukkan kemampuan pemahaman konsep operasi hitung penjumlahan bilangan cacah siswa belum optimal, hal ini dibuktikan dengan capaian rerata siswa dari satu kelas hanya mampu berada pada kategori nilai batas bawah sedang dengan nilai 44,36. Temuan 
dari penelitian ini diharapkan dapat menjadi bahan evaluasi pada guru untuk peningkatan kualitas proses belajar mengajar di kelas khususnya pada pemahaman konsep operasi hitung penjumlahan bilangan cacah. Penelitian ini memiliki keterbatasan dalam hal skala sampel yang masih terbatas pada satu kelas di sebuah sekolah. Perlunya penelitian lanjutan untuk mengungkap kemampuan pemahaman operasi hitung penjumlahan cacah dengan skala yang lebih luas. Selain itu, dapat juga ditindaklanjuti dengan upaya bagaimana mengatasi kondisi hasil belajar yang belum optimal dengan melakukan intervensi melalui inovasi dalam proses pembelajaran di sekolah dasar.

\section{DAFTAR RUJUKAN}

Ainurrohmah, N., \& Mariana, N. (2016). Refleksi Kritis Terhadap Pandangan Matematika dari PErspektif Siswa dan PEndidik Sekolah Dasar. JPGSD Universitas Negeri Surabaya, 6(10), 1706-1717.

Arnidha, Y. (2015). Analisis Kesalahan Siswa dalam Menyelesaikan Soal Operasi Hitung Bilangan Cacah. Jurnal E-DuMath, 1(1), 52-63.

Astuty, K. Y., \& Wijayanti, P. (2013). Analisis Kesalahan Siswa Kelas V dalam Menyelesaikan Soal Matematika Pada Materi Pecahan di SDN MEdokan Semampir I/259 Surabaya. Jurnal MATHEdunesa, 2(3), 1-7.

Depdiknas. (2006). Kurikulum Tingkat Satuan Pendidikan (KTSP). Jakarta.

Dewi, S. R., \& Haryanto, H. (2019). Pengembangan Multimedia
Interaktif PEnjumlahan pada Bilangan Bulat untuk Siswa Kelas IV Sekolah Dasar. Premiere Educandum: Jurnal Pendidikan Dasar Dan Pembelajaran, 9(April), 9-22. https://doi.org/10.25273/pe.v9i1. 3059

Fitriana, N. (2016). Peningkatan Kemampuan Melakukan Operasi Bilangan dengan Media Lingkungan Alam.

Heather C. Hill, D. L. B. and S. G. S. (2008). Unpacking Pedagogical Content Knowledge: Conceptualizing and Measuring Teachers' Topic-Specific Knowledge of Students. Journal for Research in Mathematics Education, 39(4), 372-400.

Imelda, M., Yusmin, E., \& Suratman, D. (2014). Profil kesalahan siswa dalam menyelesaikan soal operasi hitung campuran bilangan bulat di SMP. Jurnal Pendidikan Dan Pembelajaran, 3(2), 1-13.

Mulyani, N. S., Suarjana, I., \& Renda, N. T. (2018). Analisis Kemampuan Siswa dalam Menyelesaikan Operasi Hitung Penjumlahan dan Pengurangan Bilangan Bulat. Jurnal Ilmiah Sekolah Dasar, 2(3), 266-274.

Oktaviyani, H., \& Karlimah, K. (2019). Peningkatan Pemahaman Konsep Operasi Hitung Penjumlahan Bilangan Cacah pada Siswa SD Menggunakan Media Pop Up Book. PEDADIDAKTIKA: Jurnal Ilmiah Pendidikan Guru Sekolah Dasar, 6(1), 203-210.

Putri, I. I. P. (2011). Implementasi Alat Peraga Operasi Bilangan Bulat Bagi Guru Sekolah Dasar ( 
SD ) Se-Kecamatan Ilir Barat I Palembang. Jurnal Pendidikan Matematika, 5(1), 73-79.

Siagian, M. D. (2016). Kemampuan Koneksi Matematik dalam Pembelajaran Matematika. Journal of Mathematics Education and Science, 2(1), 5867.

Sulianto, J. (2008). Pendekatan Konstekstuakl dalam Pembelajaran Matematika untuk Meningkatkan BErpikir Kritis pada SIswa Sekolah Dasar. Jurnal Pythagoras, 4(2), 14-25.

Suryowati, E. (2016). Concept Image Siswa SD tentang Pecahan pada Garis Bilangan. In Prosiding: Seminar Nasional Pendidikan Matematika IAIN Tulung Agung (pp. 101-108).

Ugi, L. E., Djadir, D., \& Darwis, M. (2016). Analisis KEsalahan Siswa Pada Operasi Hitung
Campuran Bilangan Bulat dan Alternatif Pemecahannya. Jurnal Daya Matematis, 4(1), 34-50.

Utami, L. (2016). Analisis Kesulitan Siswa SMP Kelas VII dalam Menyelesaikan Soal Operasi Hitung Bilangan dan Solusi Pemecahannya. In Konferensi Nasional Penelitian Matematika dan Pembelajarannya (KNPMP I) (pp. 246-259). Surakarta: Universitas Muhammadiyah Surakarta.

Wahyudi, W. (2009). Kesalahan Hitung Pengurangan Bilangan Cacah bagi Siswa Sekoah Dasar. Jurnal Pedagogia, 12(2).

Widyastuti, N. S., \& Pujiastuti, P. (n.d.). Pengaruh Pendidikan Matematika Realistik Indonesia (PMRI) terhadap Pemahaman Konsep dan Berpikir Logis Siswa. Jurnal Prima Edukasia, 2(2), 183-193. 